\title{
Is there any Proffitt in stair climbing? A headcount of studies testing for demographic differences in choice of stairs
}

\author{
Frank F. Eves
}

Published online: 18 June 2013

(C) The Author(s) 2013. This article is published with open access at Springerlink.com

\begin{abstract}
The apparent slope of a hill, termed geographical slant perception, is overestimated in explicit awareness. Proffitt (2006) argued that overestimation allows individuals to manage their locomotor resources. Increasing age, fatigue, and wearing a heavy back pack will reduce the available resources and result in steeper reports for a particular hill. In contrast, Durgin and colleagues have proposed an alternative explanation for these effects based on experimental designparticularly, the potential effects of experimental demand. Proffitt's resource-based model would predict that pedestrians with reduced resources should avoid climbing a hill that would further deplete their resources if the opportunity arose. Within the built environment, stairs are the man-made equivalent of relatively steep hills $\left(20^{\circ}-30^{\circ}\right)$. In many public access settings, pedestrians can avoid climbing the stairs by opting for an adjacent escalator. Observations of pedestrian behavior in shopping malls reveal that $94.5 \%$ do so. This article summarizes the effects of demographic grouping on avoidance of stairs in public health research. Observations in shopping malls $(n=355,069)$ and travel contexts $(n=$ $711,867)$ provide data consistent with Proffitt's resource model. Women, the old, and those carrying excess body weight or large bags avoid the stairs more than do their comparison groups. Discussion focuses on differences in physiology that may underlie avoidance of stair climbing in order to highlight the pedestrian behavior that psychology needs to explain.
\end{abstract}

Keywords Geographical slant perception - Stair climbing · Locomotion $\cdot$ Resource costs $\cdot$ Pedestrian behavior

F. F. Eves $(\bowtie)$

School of Sport and Exercise Sciences, University of Birmingham, Edgbaston, Birmingham B15 2TT, UK

e-mail: f.f.eves@bham.ac.uk

\section{Introduction}

Walking for transport is one of the oldest and most common of human locomotor behaviors. Using as it does large muscle masses, walking requires 4 times the energetic resources of the resting state. Proffitt (2006) argued that the available resources for walking are reflected in perception of the environment. When resources are depleted, the perceived distance of a level journey and the steepness of a climb are increased in line with any depletion. Proffitt argued that this malleability occurs because perception is related to an economy of action. Scaling of slant perception by available resources simplifies planning, in that individuals do not need to explicitly relate the slant of the hill to their current state (Proffitt, 2006).

In a seminal paper, Proffitt, Bhalla, Gossweiler, and Midgett (1995) investigated perception of hill slopes, termed geographical slant perception. Individuals standing at the base of a hill estimated its slant verbally in degrees and used a visual matching task in which they adjusted a wedge-shaped segment of a disk until the angle of the segment matched the crosssectional angle of the hill. These explicit verbal and visual measures revealed overestimation such that a $5^{\circ}$ hill was reported to be $20^{\circ}$ and a $10^{\circ}$ hill as $30^{\circ}$. Within Proffitt's account, conscious perception of slant, exemplified by the verbal and visual measures, allows an individual to plan a subsequent locomotor behavior in relation to his or her available resources. For example, Proffitt and co-workers reported that manipulations that deplete an individual's resources - that is, wearing a heavy backpack or going for a fatiguing runincreased explicit reports of the slant of a particular hill, relative to those unaffected (Bhalla \& Proffitt, 1999; Proffitt et al., 1995). Others, however, have challenged this account, arguing that demand characteristics can provide a plausible alternative explanation for the effects of manipulations (e.g., Durgin et al., 2009; Durgin, Hajnal, Li, Tonge, \& Stigliani, 2010). A participant judging hill slant when wearing a heavy backpack or 
following a fatiguing run may "deduce" that the hill should appear steeper and "cooperate" with the experimenter.

One key variable missing from this debate is behavior. Neither Proffitt nor his detractor Durgin measured locomotion itself, focusing instead on perception. But Proffitt's contention is a functional one, about pedestrians and the perception that subserves pedestrian behavior. It is the naturally occurring behavior of pedestrians that needs explaining. Humans optimize the energetic consequences of locomotion. We adopt a step width and stride frequency for walking and choose a stride length and frequency for running, all of which minimize the total metabolic cost (see Srinivasan, 2009). We choose speeds for walking and running that minimize energetic cost per unit distance (Hreljac, 1993; Streudel-Numbers \& WallScheffler, 2009). Minimization of hill-climbing cost also occurs. Minetti (1995) calculated that the energetically optimum path for humans' climbing would become a zigzag at slopes greater than $14^{\circ}$, with each straight section rising with a gradient of $0.25\left(14^{\circ}\right)$. Contour maps of footpaths in the Alps and Himalayas matched these predictions, with deviation from the direct route up the mountain above the critical gradient. Although the available data were sparse, the effects of elevation suggest that this choice did not reflect concern about falling on steeper slopes. At higher elevations - that is, above $4,000 \mathrm{~m}$, where reduced oxygen pressure constrains energetic resources - the change to a zigzag path occurs at shallower slopes than lower down. In this instance of minimization, paths summarize repeated pedestrian choices required for their appearance. Slant influences choice, and Proffitt's resource model makes clear predictions about choice. Where options are available, behavior should be biased away from use of resources. Data from the public health literature can test this prediction. Often, pedestrians in the built environment can avoid expending resources to climb stairs by choosing an adjacent escalator. Observations in shopping centers confirm that avoidance is prominent; on average, $94.5 \%$ choose the escalator (Eves \& Webb, 2006). ${ }^{1}$

Central to the data on stair avoidance are the potential effects of demographic grouping on resources. Climbing requires leg strength to raise the center of mass over the support foot and free the trailing leg so that it can be positioned on the hill above. Leg strength declines with age, and older participants require a greater proportion of their available resources for a climb (Allied Dunbar National Fitness Survey, 1992). Consistent with declining resources, older participants reported steep hills - for example, $25^{\circ}$ - as steeper than did their younger counterparts (Bhalla \& Proffitt, 1999). The demographic of sex is also relevant here; women reported hills as steeper than did men, a difference that has provoked little

\footnotetext{
${ }^{1}$ While escalators can provide a quicker ascent (Eves, Lewis, \& Griffin, 2008 ), only $8.5 \%$ walk up them, consistent with journey time as a reason for stair avoidance (Eves \& Hoppé, unpublished results).
}

comment. On average, women have a greater percentage of body fat than do men - that is, carry more dead weight - yet have lower leg strength (McCardle, Katch, \& Katch, 2007). The net outcome of these physiological differences is that climbing the same hill would require a greater percentage of the available resources of a woman, relative to a man of the same age, weight, fitness, and health.

Concerning demographics, Proffitt's model would predict that avoidance of resource depletion would be more frequent in those subgroups with reduced resources for the same climb. Women, the old, and those carrying large bags should be more likely to avoid stairs by choosing the escalator. Thus, naturally occurring choices made by pedestrians can provide behavioral evidence of the avoidance of resource depletion that would be predicted by an account based on economy of action. These data cannot demonstrate that perception influences behavior. Nonetheless, avoidance in the observational data, stratified by differences in resources available to different demographic groups, appears to be a prerequisite for any model in which a malleable environmental cue of perceived slant biases choice. If natural avoidance data run counter to Proffitt's account, then the model would require revision.

\section{Effects of demographic grouping on stair avoidance}

This article summarizes the effects of demographics on choice between stairs and escalators in public access settings-for example, when shopping or traveling. Metalib searches were conducted using the keyword combinations stair, escalator, use, and climbing, and all retrieved articles were inspected for relevant studies. The constraint for inclusion was at least one coded demographic. The final data set contains 43 studies with relevant information. Fifteen studies are for journeys in shopping malls where evenly distributed pedestrian traffic allows excellent observational coding of individual demographics (kappas $>.90$ ). For the remaining studies, primarily in stations $(n=28)$, pedestrian traffic flow is often higher as passengers try to leave the station simultaneously, making reliable coding of multiple demographics more challenging. Nonetheless, kappas $>.80$ would be termed excellent by the test's originators. The data were collected because inclusion of the demographics of sex, age, and presence of large bags improves statistical modeling. One further demographic is included in the table - namely, weight status. The more a pedestrian weighs, the more work he or she must do against gravity, and a resource model would predict that overweight individuals would be more likely to avoid stairs. Studies that used silhouettes to code weight status - that is, a standard to optimize observational coding confirm that avoidance is more likely in the overweight (Eves, Webb, \& Mutrie, 2006; Lewis \& Eves, 2011).

The tables summarize the statistically significant effects of demographics on stair avoidance. Each table contains a 
Table 1 Summary of the effects of demographic grouping on avoidance of the stairs in shopping malls

\begin{tabular}{|c|c|c|c|c|c|c|c|c|}
\hline Name (date) & Site & $N$ & Multi & $\begin{array}{l}\text { Females vs. } \\
\text { Males }\end{array}$ & Age & $\begin{array}{l}\text { Old vs. } \\
\text { Young }\end{array}$ & $\begin{array}{l}\text { Overweight } \\
\text { vs. Not }\end{array}$ & $\begin{array}{l}\text { Bag vs. } \\
\text { No Bag }\end{array}$ \\
\hline $\begin{array}{l}\text { Andersen, Franckowiak, Snyder, } \\
\text { Barlett, \& Fontaine (1998) }\end{array}$ & Baltimore (U.S.) & 17,901 & no & $=$ & $40 / 40+$ & $=$ & $\mathrm{OW}>\mathrm{N}$ & exclude \\
\hline \multirow[t]{3}{*}{ Kerr, Eves, \& Carroll (2001b) } & Birmingham 1 (U.K.) & 13,934 & yes & $\mathrm{F}>\mathrm{M}$ & - & - & - & - \\
\hline & Birmingham 2 (U.K.) & 16,084 & yes & $\mathrm{F}>\mathrm{M}$ & $60 / 60+$ & $\mathrm{O}>\mathrm{Y}$ & - & $\mathrm{B}>\mathrm{NB}$ \\
\hline & Birmingham 1 (U.K.) & 12,588 & yes & $\mathrm{F}>\mathrm{M}$ & $60 / 60+$ & $\mathrm{O}>\mathrm{Y}$ & - & $\mathrm{B}>\mathrm{NB}$ \\
\hline Kerr, Eves, \& Carroll (2001c) & Wolverhampton (U.K.) & 45,361 & yes & $\mathrm{F}>\mathrm{M}$ & $60 / 60+$ & $\mathrm{O}>\mathrm{Y}$ & - & $\mathrm{B}>\mathrm{NB}$ \\
\hline \multirow[t]{2}{*}{ Kerr, Eves, \& Carroll (2001a) } & Redditch (U.K.) & 12,018 & yes & $\mathrm{F}>\mathrm{M}$ & $60 / 60+$ & $\mathrm{O}>\mathrm{Y}$ & - & $=$ \\
\hline & Kidderminster (U.K.) & 11,961 & yes & $=$ & $60 / 60+$ & $\mathrm{O}>\mathrm{Y}$ & - & $=$ \\
\hline Webb \& Eves (2005) & Wolverhampton (U.K.) & 32,597 & yes & $\mathrm{F}>\mathrm{M}$ & $60 / 60+$ & $\mathrm{O}>\mathrm{Y}$ & - & $\mathrm{B}>\mathrm{NB}$ \\
\hline $\begin{array}{l}\text { Nomura, Enoki, Okezaki, } \\
\quad \text { \& Sato (2006) }\end{array}$ & Kochi City (Japan) & 9,834 & yes & $=$ & $65 / 65+$ & $\mathrm{O}>\mathrm{Y}$ & & $\mathrm{B}>\mathrm{NB}$ \\
\hline \multirow[t]{2}{*}{ Webb \& Eves (2007b) } & Birmingham 1 (U.K.) (exp.) & 29,713 & yes & $\mathrm{F}>\mathrm{M}$ & $60 / 60+$ & $\mathrm{O}>\mathrm{Y}$ & - & $\mathrm{B}>\mathrm{NB}$ \\
\hline & Birmingham 3 (U.K.) (gen.) & 47,553 & yes & $\mathrm{F}>\mathrm{M}$ & $60 / 60+$ & $\mathrm{O}>\mathrm{Y}$ & - & $\mathrm{B}>\mathrm{NB}$ \\
\hline Webb \& Eves (2007a) & Coventry (U.K.) & 42,313 & yes & $\mathrm{F}>\mathrm{M}$ & $60 / 60+$ & $\mathrm{O}>\mathrm{Y}$ & - & $\mathrm{B}>\mathrm{NB}$ \\
\hline $\begin{array}{l}\text { Eves, Masters, McManus, } \\
\text { Leung, Wong \& White (2008) }\end{array}$ & Lok Fu (Hong Kong) & 18,257 & yes & $=$ & $60 / 60+$ & $=$ & - & $\mathrm{B}>\mathrm{NB}$ \\
\hline Webb \& Cheng (2010) & Nottingham (U.K.) & 20,807 & yes & $\mathrm{F}>\mathrm{M}$ & - & - & $\mathrm{OW}>\mathrm{N}$ & $=$ \\
\hline Eves \& Hoppé (unpub) & Birmingham 1 (U.K.) & 24,148 & yes & $\mathrm{F}>\mathrm{M}$ & - & - & - & exclude \\
\hline Overall total & & 355,069 & & $11 / 15$ & & $10 / 12$ & $2 / 2$ & $9 / 12$ \\
\hline
\end{tabular}

Note. "Multi" indicates whether the results were from multivariate analyses, and "Age" gives the distinction between age groups that coders were asked to make. For the body of the table, = indicates no significant differences between the demographic groups in that column, - indicates that the demographic grouping was not coded in that study, $>$ indicates that one group avoided stairs more than the other (e.g., $\mathrm{F}>\mathrm{M}$ means that females avoided stairs more than did men). Exp. = experimental staircase, gen. = generalization staircase, $\mathrm{F}=$ females, $\mathrm{M}=$ males, $\mathrm{O}=$ older pedestrians, $\mathrm{Y}=$ younger pedestrians, $\mathrm{OW}=$ overweight pedestrians, $\mathrm{N}=$ not overweight, $\mathrm{B}=$ indicates those carrying a large bag, $\mathrm{NB}=$ those without a large bag. "Exclude" indicates that individuals encumbered with large bag were not coded in that study.

column labeled "Multi" that indicates whether the results were from multivariate analyses. Natural variation in the pedestrians using a site means that coding for multiple demographics may not be fully independent. For example, age and weight status may covary, and multivariate analyses are preferable. It should be noted that where multivariate analyses have been employed, the effects of a particular demographic are independent of, and may be additive to, any other coded variable. The column labeled "Age" gives the distinction between age groups that coders were asked to make, with the next column showing whether any differences between these ages occurred. Finally, some studies did not code individuals carrying large bags a priori, since it might constrain choice, and exclusion of this group is indicated in the final column.

Stair avoidance in shopping malls

Table 1 summarizes the effects of demographic grouping in shopping malls, primarily in the U.K. The studies conducted in Birmingham used three different staircases, with the number following the location indicating where the same staircase was used in different studies. Webb and Eves (2007b) included both an experimental staircase where an intervention was installed (exp.) and a staircase with no intervention to test for generalization of the intervention to a staircase without it (gen.). Inspection of Table 1 reveals data consistent with an account based on the economy of action. Overall, women, the old, the overweight, and those carrying large bags were more likely to avoid stairs than were their comparison groups. No studies reported the opposite relationship.

\section{Stair avoidance in travel contexts}

Table 2 summarizes the effects of demographic grouping on behavior in travel contexts from a range of countries. It has been separated into two sections. The first section only contains studies in stations $(n=20)$, with some unpublished ongoing research providing relevant data. The second section contains miscellaneous travel contexts. Data for the studies by Brownell, Stunkard, and Albaum, (1980) and Meyers, Stunkard, Coll, and Cooke (1980) were collected across a number of different sites, primarily travel ones, but were not broken down by site. Nonetheless, they provide rare information on the effects of weight status and are included. While the study in an airport by Adams et al. (2006) combined stair ascent and descent, coding from video records provided a rich source of information, and the study was included too. The last three rows in this section contain 
Table 2 Summary of the effects of demographic grouping on stair avoidance in travel contexts

\begin{tabular}{|c|c|c|c|c|c|c|c|c|}
\hline Name (date) & Site & $N$ & Multi & $\begin{array}{l}\text { Females vs. } \\
\text { Males }\end{array}$ & Age & $\begin{array}{l}\text { Old vs. } \\
\text { Young }\end{array}$ & $\begin{array}{l}\text { Overweight } \\
\text { vs. Not }\end{array}$ & $\begin{array}{l}\text { Bag vs. } \\
\text { No Bag }\end{array}$ \\
\hline $\begin{array}{l}\text { Brownell, Stunkard, \& } \\
\text { Albaum (1980) }\end{array}$ & Station (U.S.) & 24,603 & no & $\mathrm{F}>\mathrm{M}$ & $30 / 30+$ & $\mathrm{O}>\mathrm{Y}$ & OW $>\mathrm{N}$ & exclude \\
\hline Blamey, Mutrie, \& Aitchison (1995) & Station (Scotland) & 22,275 & yes & $\mathrm{F}>\mathrm{M}$ & - & - & - & exclude \\
\hline Kerr, Eves, \& Carroll (2001b) & Station (England) & 25,319 & yes & $\mathrm{F}>\mathrm{M}$ & - & - & - & exclude \\
\hline Andersen et al. (2006) & Station (U.S.) & 16,035 & no & $=$ & $40 / 40+$ & $=$ & $\mathrm{OW}>\mathrm{N}$ & exclude \\
\hline \multirow{2}{*}{$\begin{array}{l}\text { Iversen, Händel, Jensen, } \\
\text { Frederiksen, \& Heitman } \\
\text { (2007) }\end{array}$} & Station (Denmark) & 6,264 & yes & $=$ & - & - & - & exclude \\
\hline & Station (Denmark) & 25,818 & yes & $=$ & - & - & - & exclude \\
\hline $\begin{array}{l}\text { Olander, Eves, \& Puig } \\
\quad \text { Ribera (2008) }\end{array}$ & Station (England) & 36,239 & yes & $\mathrm{F}>\mathrm{M}$ & - & - & - & exclude \\
\hline $\begin{array}{l}\text { Eves, Olander, Nicoll, Puig } \\
\text { Ribera, \& Griffin (2009) }\end{array}$ & Station (England) & 41,717 & yes & $\mathrm{F}>\mathrm{M}$ & - & - & - & exclude \\
\hline $\begin{array}{l}\text { Nomura, Yoshimoto, Akezaki, } \\
\quad \text { \& Sato (2009) }\end{array}$ & Station (Japan) & 43,241 & yes & $\mathrm{F}>\mathrm{M}$ & Student/ $65 / 65+$ & $\mathrm{O}>\mathrm{Y}$ & - & - \\
\hline Puig-Ribera \& Eves (2010) & Station (Spain) & 33,119 & yes & $\mathrm{F}>\mathrm{M}$ & $60 / 60+$ & $\mathrm{O}>\mathrm{Y}$ & - & $\mathrm{B}>\mathrm{NB}$ \\
\hline Müller-Riemenschneider et al. (2010) & Station (Germany) & 1,557 & no & $\mathrm{F}>\mathrm{M}$ & - & - & - & \\
\hline \multirow{2}{*}{$\begin{array}{l}\text { Ryan, Lyon, Webb, Eves, \& } \\
\quad \text { Ryan (2011) }\end{array}$} & Station (Scotland) & 5,056 & yes & $\mathrm{F}>\mathrm{M}$ & - & - & - & exclude \\
\hline & Station (Scotland) & 15,259 & yes & $\mathrm{F}>\mathrm{M}$ & - & - & - & exclude \\
\hline Lewis \& Eves (2011) & Station (England) & 23,121 & yes & $\mathrm{F}>\mathrm{M}$ & - & - & $\mathrm{OW}>\mathrm{N}$ & exclude \\
\hline Andersen \& Bauman (2011) & Station (U.S.) & 9,766 & no & $=$ & $40 / 40+$ & $\mathrm{O}>\mathrm{Y}$ & $\mathrm{OW}>\mathrm{N}$ & exclude \\
\hline Lewis \& Eves (2012) & Station (England) & 38,697 & yes & $\mathrm{F}>\mathrm{M}$ & - & - & - & exclude \\
\hline \multirow[t]{3}{*}{ Eves \& Puig-Ribera (unpub) } & Station (Spain) & 36,479 & yes & $\mathrm{F}>\mathrm{M}$ & $60 / 60+$ & $\mathrm{O}>\mathrm{Y}$ & - & $\mathrm{B}>\mathrm{NB}$ \\
\hline & Station (Spain) & 31,302 & yes & $\mathrm{F}>\mathrm{M}$ & $60 / 60+$ & $\mathrm{O}>\mathrm{Y}$ & - & $\mathrm{B}>\mathrm{NB}$ \\
\hline & Station (Holland) & 37,479 & yes & $\mathrm{F}>\mathrm{M}$ & - & - & - & exclude \\
\hline Eves \& Thorpe (unpub) & Station (England) & 2,510 & yes & $\mathrm{F}>\mathrm{M}$ & $60 / 60+$ & $\mathrm{O}>\mathrm{Y}$ & - & $\mathrm{B}>\mathrm{NB}$ \\
\hline Subtotal & & & & $16 / 20$ & & $7 / 8$ & $4 / 4$ & $4 / 4$ \\
\hline $\begin{array}{l}\text { Brownell, Stunkard, \& } \\
\text { Albaum (1980) }\end{array}$ & $\begin{array}{l}\text { Mall, bus, and train } \\
\text { station (USA) }\end{array}$ & 21,091 & no & $\mathrm{F}>\mathrm{M}$ & $30 / 30+$ & $\mathrm{O}>\mathrm{Y}$ & $\mathrm{OW}>\mathrm{N}$ & exclude \\
\hline $\begin{array}{l}\text { Meyers, Stunkard, Coll, \& } \\
\text { Cooke (1980) }\end{array}$ & $\begin{array}{l}\text { Mall, airport, bus, and } \\
\text { train station (U.S.) }\end{array}$ & 3,217 & no & - & - & - & $\mathrm{OW}>\mathrm{N}$ & exclude \\
\hline Russell \& Hutchinson (2000) & Airport (U.S.) & 3,369 & yes & $\mathrm{M}>\mathrm{F}$ & $40 / 40+$ & $\mathrm{O}>\mathrm{Y}$ & - & exclude \\
\hline Coleman \& Gonzalez (2001) & Airport (U.S.) & 34,125 & no & $\mathrm{F}>\mathrm{M}$ & - & - & - & exclude \\
\hline Adams et al. (2006) & Airport (U.S.) & 15,574 & yes & $\mathrm{F}>\mathrm{M}$ & youth/adult/senior & $\mathrm{O}>\mathrm{Y}$ & $\mathrm{OW}>\mathrm{N}$ & $\mathrm{B}>\mathrm{NB}$ \\
\hline Eves \& Masters (2006) & Travelator (Hong Kong) & 57,801 & yes & $\mathrm{F}>\mathrm{M}$ & $60 / 60+$ & $\mathrm{O}>\mathrm{Y}$ & - & exclude \\
\hline \multirow[t]{2}{*}{ Eves et al. (2008) } & Travelator (Hong Kong) & 76,710 & yes & $\mathrm{F}>\mathrm{M}$ & $60 / 60+$ & $\mathrm{O}>\mathrm{Y}$ & - & exclude \\
\hline & Stairs (Hong Kong) & - & yes & $M>F$ & $60 / 60+$ & $\mathrm{O}>\mathrm{Y}$ & - & exclude \\
\hline Subtotal & & & & $5 / 7$ & & $6 / 6$ & $3 / 3$ & $1 / 1$ \\
\hline Grand Total & & 711,867 & & $21 / 27$ & & $13 / 14$ & $7 / 7$ & $5 / 5$ \\
\hline
\end{tabular}

Note. "Multi" indicates whether the results were from multivariate analyses, and "Age" gives the distinction between age groups that coders were asked to make. For the body of the table, = indicates no significant differences between the demographic groups in that column, - indicates that the demographic grouping was not coded in that study, $>$ indicates that one group avoided stairs more than the other (e.g., F $>$ M means females avoided stairs more than did men). $\mathrm{F}=$ females, $\mathrm{M}=$ males, $\mathrm{O}=$ older pedestrians, $\mathrm{Y}=$ younger pedestrians, $\mathrm{OW}=$ overweight pedestrians, $\mathrm{N}=$ not overweight, $\mathrm{B}=$ indicates those carrying a large bag, $\mathrm{NB}=$ those without a large bag. "Exclude" indicates that individuals encumbered with large bag were not coded in that study.

studies conducted on the Mid-Levels escalator system in Hong Kong. This series of escalators and stairs is a pedestrian transit system that reduces motorized traffic in the city. For two of the lower sections of this system, the mechanized alternative to stairs is a travelator-that is, an escalator without steps. The travelator of the studies shown in the table climbed $5.72 \mathrm{~m}$ over a total length of $57.5 \mathrm{~m}\left(\right.$ angle $\left.=5.7^{\circ}\right)$. Stair use was very low in this setting $(0.75 \%)$, and hence, coding of individuals who walked up this moving slope was performed. In effect, this represents a metal "hill" and provides the only information on "hill" climbing in the data set. 
Once again, inspection of Table 2 reveals data consistent with an account based on economy of action. Overall, women, the old, the overweight, and those carrying large bags were more likely to avoid stairs than were their comparison groups. Two studies reported the opposite relationship for sex, one with a relatively small sample (Russell \& Hutchinson, 2000). In Eves, Masters, McManus, Leung, Wong and White (2008), stair climbing was rare $(0.75 \%)$, and the climate in Hong Kong may be relevant (see the Discussion section). The remaining demographic differences were always in the predicted direction. Additionally, walking up the metal "hill" of the travelator in Hong Kong was avoided more, overall, by women and older pedestrians than by their comparison groups.

\section{Analysis}

These data on statistically significant effects of demographic grouping in the studies do not need meta-analysis. Simple tests of predictions derived from Proffitt's model on the combined data from the tables with the binomial test revealed that women avoided the stairs more frequently than did men $(32 / 42, p=.0005)$, the old more frequently than the young $(23 / 26, p=.00005)$, the overweight more than those coded as healthy weight $(9 / 9, p=.002)$, and those carrying large bags more than the unencumbered $(14 / 17, p=.006)$.

\section{Discussion}

In summary, behavioral choices made in shopping and travel contexts were consistent with Proffitt's model; demographic groups with reduced resources were more likely to avoid climbing stairs when the opportunity arose. Observations of pedestrian behavior are unlikely to be confounded with experimental demand; the pedestrians were not taking part in any experiment. These data cannot resolve the dispute between Proffitt and Durgin. Rather, they describe the natural behavior that needs to be explained. Nonetheless, the tables have been organized on a continuum from less to more potential for explicit consideration by an individual of the effects of their particular demographic on behavior. Carrying a bag is clearly the most explicit, since it was chosen at the outset, and appears in the far right column of the tables. The remaining demographics all have the potential for explicit consideration. It seems likely, however, that age and weight would be more explicit to the pedestrian than his or her gender when making a journey. Therefore, the comparisons for sex are positioned to the left of the tables. The data do not suggest progressively more avoidance as the potential for explicit consideration of the demographic increases.

Concerning explicit thinking about one's demographic when making a journey, a distinction made by Woods,
Philbeck, and Danoff (2009) when testing potential explicit effects on perception of distance is pertinent. Participants can make judgments on the basis of where they "think the object really is," what Woods et al., termed objective estimates, or participants can include nonvisual factors, judging on the basis of where they "feel it is" (Woods et al., 2009, p. 1113). It seems likely that a pedestrian navigating the built environment will choose behavior on the basis of how they "feel," rather than making a carefully considered perceptual decision about the alternatives, particularly if preoccupied with the purpose of the journey they are making.

Two further points about the demographics of climbing seem pertinent. Concerning age, Durgin et al. (2010) highlighted potential effects of experimental demand and queried the absence of an overall effect of age on hill perception in Bhalla and Proffitt (1999). Stairs represent relatively steep slopes (i.e.,

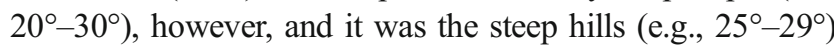
that older participants reported as steeper (Bhalla \& Proffitt, 1999). To climb stairs, individuals require sufficient strength in their legs to raise their weight onto the support foot so that the next foot can be placed on the step above. Declining leg strength with age means that older individuals require a greater proportion of their available resources to climb (Reeves, Spanjaard, Mohagheghi, Baltzopoulos, \& Maganaris, 2009). Thus, differences for steep slopes appear consistent with declining resources - specifically, in the ability to raise body weight above the support foot that is predicted by leg strength (Konczak, Meeuwsen, \& Cress, 1992).

While common sense notions of behavior might predict greater avoidance in older individuals and those encumbered with additional weight, potential explanations for sex differences in avoidance are less obvious. The more frequent avoidance by women is not attributable to restrictive clothing such as skirts (Kerr, 2001) or high heels (Adams et al., 2006; Kerr, 2001). In contrast, stair climbing would require a greater proportion of the available resources for climbing of an average women, as compared with an average man. Furthermore, sex differences in the underlying physiology that influence the avoidance of climbing are not unidirectional. Physical activity always produces excess heat that must be dissipated, and climate is relevant. Any need to lose heat increases the blood supply to the skin at the expense of exercising muscles and, hence, reduces locomotor resources. Men and women differ in the way that they dissipate heat. Women have a greater surface area per unit mass than do men and, as a result, are better able to radiate heat from their body. In contrast, men rely more on evaporative heat loss - that is, sweating (McCardle et al., 2007). Increases in temperature and humidity would be more detrimental to thermoregulation via sweating than via radiant heat loss. Walking up the metal "hill" of the travelator in Hong Kong decreased as humidity and temperature increased (Eves \& Masters, 2006; Eves et al., 2008). These effects of climate were greater in males ( $38 \%$ of the variance) than in females 
( $12 \%$ of the variance). Men avoided walking more than did women as humidity increased. The point here is that a difference in the physiology between the sexes was echoed in locomotor choices such that men avoided climbing the travelator more than did women as the climatic conditions became less favorable and also avoided stairs more in that study. Normally for stairs, however, the underlying physiology predicts the opposite effect, greater avoidance for women than for men.

\section{Conclusions}

Although this summary of the effects for demographic grouping on stairs avoidance is consistent with Proffitt's resource model, the data simply document a concordance between demographic differences in perception and behavior. No perceptual measures of slant were obtained. Nonetheless, biases in behavioral choice that are consistent with locomotor resources are the natural behavior of pedestrians that must be explained by any embodied account of locomotion.

Acknowledgments I thank Susannah Thorpe, Guy Taylor-Covill and Rob Gray for insightful comments on earlier drafts and Takuo Nomura for providing me with the analyses for the effects of demographics in the two studies for which he is the first author.

Open Access This article is distributed under the terms of the Creative Commons Attribution License which permits any use, distribution, and reproduction in any medium, provided the original author(s) and the source are credited.

\section{References}

Adams, M. A., Hovell, M. F., Irvin, V., Sallis, J. F., Coleman, K. J., \& Liles, S. (2006). Promoting stair use by modeling: An experimental application of the behavioral ecological model. American Journal of Health Promotion, 21, 101-109. doi:10.4278/0890-1171-21.2.101

Allied Dunbar National Fitness Survey. (1992). A report commissioned by the Sports Council and Health Education Authority. London: Sports Council.

Andersen, R. E., \& Bauman, A. E. (2011). The effects of commuter pedestrian traffic on the use of stairs in an urban setting. American Journal of Health Promotion, 26, 49-52. doi:10.4278/ajhp.100202ARB-39

Andersen, R. E., Franckowiak, S. C., Snyder, J., Barlett, S. J., \& Fontaine, K. R. (1998). Physical activity promotion by the encouraged use of stairs. Annals of Internal Medicine, 129, 363-369.

Andersen, R. E., Franckowiak, S. C., Zuzak, K. B., Cummings, E. S., Barlett, S. J., \& Crespo, C. J. (2006). Effects of a culturally sensitive sign on the use of stairs in African American commuters. Sozial und Praventive Medizin., 51, 373-380. doi:10.1007/s00038-006-5095-5

Bhalla, M., \& Proffitt, D. R. (1999). Visual-motor recalibration in geographical slant perception. Journal of Experimental Psychology; Human Perception and Performance, 25, 1076-1096. doi:10.1037/ 0096-1523.25.4.1076

Blamey, A., Mutrie, N., \& Aitchison, T. (1995). Health promotion by encouraged use of stairs. British Medical Journal, 311, 289-290. doi:10.1136/bmj.311.7000.289
Brownell, K. D., Stunkard, A., \& Albaum, J. (1980). Evaluation and modification of exercise patterns in the natural environment. American Journal of Psychiatry, 137, 1540-1545.

Coleman, K. J., \& Gonzalez, E. C. (2001). Promoting stair use in a U.S.Mexico border community. American Journal of Public Health, 91, 2007-2009. doi:10.2105/AJPH.91.12.2007

Durgin, F. H., Baird, J. A., Greenburg, M., Russell, R., Shaughnessy, K., \& Waymouth, S. (2009). Who is being deceived? The experimental demands of wearing a backpack. Psychonomic Bulletin \& Review, 16, 964-969. doi:10.3758/PBR.16.5.964

Durgin, F. H., Hajnal, A., Li, Z., Tonge, N., \& Stigliani, A. (2010). Palm boards are not action measures: An alternative to the two-systems theory of geographical slant perception. Acta Psychologica, 134, 182-197. doi:10.1016/j.actpsy.2010.01.009

Eves, F. F., Lewis, A. L., \& Griffin, C. (2008). Modeling effects of stair width on rates of stair climbing in a train station. Preventive Medicine, 47, 270-272. doi:10.1016/j.ypmed.2007. 12.008

Eves, F. F., \& Masters, R. S. W. (2006). An uphill struggle: Effects of a point-of-choice stair climbing intervention in a non-English speaking population. International Journal of Epidemiology, 35, 1286 1290. doi:10.1093/ije/dyl141

Eves, F. F., Masters, R. S. W., McManus, A., Leung, M., Wong, P., \& White, M. J. (2008). Contextual barriers to lifestyle physical activity interventions in Hong Kong. Medicine and Science in Sports and Exercise, 40, 965-971. doi:10.1249/MSS.0b013e3181659c68

Eves, F. F., Olander, E. K., Nicoll, G., Puig Ribera, A., \& Griffin, C. (2009). Increasing stair climbing in a train station; effects of contextual variables and visibility. Journal of Environmental Psychology, 29, 300-303. doi:10.1016/j.jenvp.2008.10.002

Eves, F. F., \& Webb, O. J. (2006). Worksite interventions to increase stair climbing; Reasons for caution. Preventive Medicine, 43, 4-7. doi:10.1016/j.ypmed.2006.03.011

Eves, F. F., Webb, O. J., \& Mutrie, N. (2006). A workplace intervention to promote stair climbing: Greater effects in the overweight. Obesity, 14, 2210-2216. doi:10.1038/oby.2006.259

Hreljac, A. (1993). Preferred and energetically optimal gait transition speeds in human locomotion. Medicine and Science in Sports and Exercise, 25, 1158-1162. doi:10.1249/00005768199310000-00012

Iversen, M. K., Händel, M. N., Jensen, E. N., Frederiksen, P., \& Heitman, B. L. (2007). Effect of health-promoting posters placed on the platforms of two train stations in Copenhagen, Denmark, on the choice between taking the stairs or the escalator: A secondary publication. International Journal of Obesity, 31, 950-955. doi:10.1038/sj.ijo.0803497

Kerr, J. (2001). Prompting stair climbing. UK: Unpublished PhD, University of Birmingham.

Kerr, J., Eves, F., \& Carroll, D. (2001a). Encouraging stair use: Banners are better than posters. American Journal of Public Health, 91, 1192-1193. doi:10.2105/AJPH.91.8.1192

Kerr, J., Eves, F., \& Carroll, D. (2001b). The influence of poster prompts on stair use: The effects of setting, poster size and content. British Journal of Health Psychology, 6, 397-405. doi:10.1348/ 135910701169296

Kerr, J., Eves, F., \& Carroll, D. (2001c). Six-month observational study of prompted stair climbing. Preventive Medicine, 33, 422-427. doi:10.1006/pmed.2001.0908

Konczak, J., Meeuwsen, H. J., \& Cress, M. E. (1992). Changing affordances in stair climbing: The perception of maximum climbability in young and older adults..Journal of Experimental Psychology. Human Perception and Performance, 18, 691-697. doi:10.1037/0096-1523.18.3.691

Lewis, A., \& Eves, F. F. (2011). Specific effects of a calorie-based intervention on stair climbing in overweight commuters. Annals of Behavioral Medicine, 42, 257-61. doi:10.1007/s12160-011-9283-Z 
Lewis, A., \& Eves, F. F. (2012). Prompts to increase stair climbing in stations; the effect of message complexity. Journal of Physical Activity and Health, 9, 954-961.

McCardle, W. D., Katch, F. I., \& Katch, V. L. (2007). Exercise Physiology (6th ed.). Philadelphia, US: Lippincott, Williams \& Wilkins.

Meyers, A. W., Stunkard, A. J., Coll, M., \& Cooke, C. J. (1980). Stairs, escalators and obesity. Behavior Modification, 4, 355-359. doi: $10.1177 / 014544558043005$

Minetti, A. E. (1995). Optimum gradient of mountain paths. Journal of Applied Physiology, 79, 1698-1703.

Muller-Riemenschneider, F., Nocon, M., Reinhold, T., \& Willich, S. N. (2010). Promotion of physical activity using point-ofdecision prompts in Berlin underground stations. International Journal of Environmental Research and Public Health, 7, 3063-3070. doi:10.3390/ijerph7083063

Nomura, T., Enoki, H., Okezaki, R., \& Sato, A. (2006). Promoting daily physical activity by encouraging stair using banners. Nippon Eiseigaku Zasshi, 61, 38-43. doi:10.1265/jjh.61.38

Nomura, T., Yoshimoto, Y., Akezaki, Y., \& Sato, A. (2009). Changing behavioral patterns to promote physical activity with motivational signs. Journal of Environmental Health and Preventive Medicine, 14, 20-25. doi:10.1007/s12199-008-0053-x

Olander, E. K., Eves, F. F., \& Puig Ribera, A. (2008). Promoting stair climbing: Stair-riser banners are better than posters... sometimes. Preventive Medicine, 46, 308-310. doi:10.1016/j.ypmed.2007.11.009

Proffitt, D. R. (2006). Embodied perception and the economy of action. Perspectives on Psychological Science, 1, 110-122. doi:10.1111/ j.1745-6916.2006.00008.x

Proffitt, D. R., Bhalla, M., Gossweiler, R., \& Midgett, J. (1995). Perceiving geographical slant. Psychonomic Bulletin \& Review, 2, 409-428. doi:10.3758/BF03210980

Puig-Ribera, A., \& Eves, F. F. (2010). Promoting stair climbing in Barcelona: Similarities and differences with interventions in English-speaking populations. European Journal of Public Health, 20, 100-102. doi:10.1093/eurpub/ckp059
Reeves, N. D., Spanjaard, M., Mohagheghi, A. A., Baltzopoulos, V., \& Maganaris, C. N. (2009). Older adults employ alternative strategies to operate within their maximum capabilities when ascending stairs. Journal of Electromyography and Kinesiology, 19, e57e68. doi:10.1016/j.jelekin.2007.09.009

Russell, W. D., \& Hutchinson, J. (2000). Comparison of health promotion and deterrent prompts in increasing use of stairs over escalators. Perceptual and Motor Skills, 91, 55-61.

Ryan, J., Lyon, K., Webb, O. J., Eves, F. F., \& Ryan, C. G. (2011). Promoting physical activity in a low socioeconomic area: Results from an intervention targeting stair climbing. Preventive Medicine, 52, 352-354. doi:10.1016/j.ypmed.2011.03.004

Srinivasan, M. (2009). Optimal speed for walking and running, and walking on a moving walkway. Chaos, 19(026112), 1-10. doi:10.1063/ 1.3141428

Steudel-Numbers, K. L., \& Wall-Scheffler, C. M. (2009). Optimal running speed and the evolution of hominin hunting strategies. Journal of Human Evolution, 56, 355-360. doi:10.1016/j.jhevol.2008.11.002

Webb, O. J., \& Cheng, T. F. (2010). An informational stair climbing intervention with greater effects in overweight pedestrians. Health Education Research, 25, 936-44.

Webb, O. J., \& Eves, F. F. (2005). Promoting stair use: Single versus multiple stair-riser messages. American Journal of Public Health, 95, 1543-1544. doi:10.2105/AJPH.2004.046235

Webb, O. J., \& Eves, F. F. (2007a). Effects of environmental changes in a stair climbing intervention: Generalization to stair descent. American Journal of Health Promotion, 22, 38-44. doi:10.4278/0890-117122.1.38

Webb, O. J., \& Eves, F. F. (2007b). Promoting stair climbing: Intervention effects generalize to a subsequent stair ascent. American Journal of Health Promotion, 22, 114-119. doi:10.4278/0890-1171-22.2.114

Woods, J. A., Philbeck, J. W., \& Danoff, J. V. (2009). The various perceptions of distance: An alternative view of how effort affects distance judgments. Journal of Experimental Psychology: Human Perception and Performance, 35, 1104-1117. doi:10.1037/a0013622 